\title{
O PROCESSO ELETRÔNICO DE VOTAÇÃO: Avanço ou Retrocesso?
}

\section{Reginaldo Gonçalves Gomes}

Doutorando em Direito Processual pela Pontifícia Universidade Católica de Minas Gerais. Mestre em Direito pela Universidade de Itaúna (2014). Bacharel em Direito pela Faculdade de Direito de Sete Lagoas (1999). Licenciado em Letras pela Faculdade de Letras da UFMG (1992). Pós-graduado em Ciências Penais pela Fundação Ministério Público de Minas Gerais e pós-graduado em Processo: Grandes Transformações pela Universidade de Santa Catarina em parceria com o curso LFG; pós-graduado em Direito do Estado pela Universidade Anhanguera em parceria com 0 curso LFG. Membro de diversas comissões de processo administrativo disciplinar. Atua nos seguintes ramos: Direito Constitucional, Direito Eleitoral, Direito Administrativo Disciplinar, Direito Penal, Processual Penal e Processo Civil. Professor de Direito. regisgomes@yahoo.com.br.

\section{Recebido em: 26/2/2016}

Aceito em: 6/6/2017

\section{Resumo}

A Justiça Eleitoral foi criada para realizar eleições em todo país em um período em que não havia democracia, com o cidadão sendo considerado objeto de direito e não sujeito de direitos. A instabilidade política justificou nesse primeiro momento o deslocamento de atribuições precipuamente do Executivo para o Judiciário. Após a Constituição Federal, porém, com o fortalecimento da democracia e do Estado Democrático de Direito, não há razão lógica para a manutenção dessa atribuição da Justiça Eleitoral, mormente porque, com a instalação das urnas eletrônicas, em decorrência da era tecnológica, há necessidade de um diálogo entre os verdadeiros interlocutores desse processo, que são os cidadãos. A Justiça Eleitoral, como parte integrante do poder Judiciário, não está preparada e nem foi criada para promover esse diálogo, uma vez que os juízes sempre tomaram decisões em seus gabinetes, sem a participação efetiva do cidadão.

\section{Palavras-chave}

Constituição Federal. Princípios constitucionais. Processo eletrônico de votação. Urna eletrônica. Avanço. Retrocesso.

\section{ELECTRONIC VOTING PROCESS: FORWARD OR BACKWARD?}

\section{Abstract}

The Electoral Court was set up to conduct elections across the country in a period when there was no democracy. At the time, the citizen was considered as an object of rights and not a subject of rights. Political instability justified, at that moment, the imputing duties 
primarily from the Executive to the Judiciary. However, after the Federal Constitution, with the strengthening of democracy and legal democratic state, there is no logical reason to maintain that allocation of Elections to the Judiciary Power, especially because of the implementation of electronic voting machines, due to the technological age, there is a need of dialogue between true partners in this process, who are the citizens. The Electoral Justice as part of the judiciary is not prepared nor it was created to promote this dialogue, since judges always made decisions in their offices without active citizen participation.

\section{Keywords}

Federal Constitution. Eletronic voting process. Voting machine. Forward. Backward.

\section{Sumário}

1 Introdução. 2 Princípios Fundamentais do Direito Eleitoral. 2.1 Princípios da Democracia e República. 2.2 Princípios do sufrágio universal e voto obrigatório. 2.3 Princípio da liberdade partidária. 3. Processo Eletrônico de Votação. 4. A Exclusão do Eleitor na Fiscalização de seu Próprio Voto. 5. 0 Risco da Tecnologia Manuseada por um Poder Inapto Suplantar Direitos Fundamentais. 6. Considerações Finais. 7. Referências 


\section{INTRODUÇÃO}

O Poder Judiciário é o órgão que detém a jurisdição. ${ }^{1}$ Esse importante órgão tem a função de dirimir, quando provocados, os conflitos existentes em uma relação entre duas pessoas, aplicando a lei ao caso concreto.

A Justiça Eleitoral, como órgáo do poder Judiciário, tem a missão de conduzir todo o processo eleitoral, além de aplicar a legislação eleitoral nos casos em que ela for subvertida. Ela foi criada pelo Decreto n. 21.076, de 24 de fevereiro de 1932, que instituiu o primeiro Código Eleitoral no país. Na Constituição de 1824, todavia, já constavam algumas normas eleitorais.

A Lei no 48, de 4 de maio de 1935, instituiu novo Código Eleitoral, criando o alistamento e o voto feminino era obrigatório para as mulheres que exercessem atividade remunerada e ainda regulamentou amplamente as atribuiçóes do Ministério Público Eleitoral no processo eleitoral.

A Constituição de 16 de julho de 1934, em seu artigo 82, criou o Tribunal Superior Eleitoral - TSE, os Tribunais Regionais Eleitorais - TREs, os juízes eleitorais e Juntas Eleitorais, passando esses órgáos a gozar de status constitucional. A Constituição de 1937, porém, extinguiu a Justiça Eleitoral, em razão do início do Estado Novo, de cunho preponderantemente ditatorial.

Costa ressalta que: ${ }^{2}$ a Constituição de 1937 não fez referência à Justiça Eleitoral, pois não "[...] era intenção da 'nova ordem' preocupar-se com eleiçôes".

Em 1945 é instituído outro Código Eleitoral, por meio do Decreto-Lei n. 7.586, de 25.5.1945, chamada Lei Agamenon, que trouxe como grande novidade a exclusividade dos partidos políticos na apresentação dos candidatos, tendo esse Código vigorado, com poucas alteraçóes, até o advento do Código Eleitoral de

${ }^{1}$ GRINOVER, Ada Pellegrini; CINTRA, Antônio Carlos de Araújo; DINAMARCO, Cândido Rangel. Teoria geral do processo. 19. ed. São Paulo: Malheiros Editores, 2003. p. 131.

2 COSTA, Tito. Recursos em matéria eleitoral. 4. ed. ampliada e atualizada de acordo com a Constituição de 1988. São Paulo: Editora Revista dos Tribunais, 1992. p. 29. 
1950, instituído pela Lei n. 1.164, de 24 de julho de 1950, que vigorou até a edição da Lei no 4.737, de 15 de julho de 1965, que instituiu o Código Eleitoral, em vigor atualmente.

A Justiça Eleitoral é incluída na Constituição dos Estados Unidos do Brasil, de 1946, em seu artigo 109, embora tenha apenas uma função acessória de organização das eleições para vereador, prefeito, deputado estadual e deputado federal, em razão da própria conjuntura política da época. Ressalte-se que inexistiam açóes judiciais no Código Eleitoral que tivessem alguma efetividade na cassação de registro de candidato.

De fato, a Justiça Eleitoral ao longo dessas décadas passou por vários percalços, não se firmando como um verdadeiro órgão jurisdicional. Os Códigos Eleitorais em regra não previam açóes judiciais eleitorais eficazes para o fim de enfrentar a corrupção que grassava à época e ainda persiste mesmo como a edição de várias leis para coibi-la.

Os Códigos Eleitorais náo previram nenhuma ação judicial, nem mesmo o Código Eleitoral de 1965, que tivesse a finalidade de cassar registro, diploma ou mandato. Na verdade, havia uma única previsão, que é o recurso contra expedição de diploma, contemplado em todos os Códigos, mas que tinha natureza administrativa, pois visava a atacar o diploma viciado em razão de alguma irregularidade ocorrida nas eleições. Somente após o trânsito em julgado, todavia, a decisão judicial poderia ser executada, ou seja, na prática, nenhuma eficácia tinha ou tem esse chamado recurso contra a expedição de diploma.

Após 1988, com o advento da Constituição da República Federativa do Brasil, o legislador constitucional criou a açáo de impugnação de mandato eletivo e surgiram, ainda, as ações infraconstitucionais, a saber: ação de investigação judicial eleitoral; representação por captação ilícita de sufrágio; representação por condutas vedadas; representação por arrecadação e gastos ilícitos.

O que realmente colocou a Justiça Eleitoral no cenário nacional, porém, foi a realização de eleiçóes utilizando-se de urnas eletrônicas, abolindo de vez o emprego de cédulas eleitorais, a chamada votação manual. 
A Justiça Eleitoral, sob o argumento de combate às fraudes e segurança da votação iniciou, em 1985, a inclusão da tecnologia na realização das eleiçôes, utilizando-se de um cadastro informatizado. Em 1995 o Tribunal Superior Eleitoral (TSE) formou uma comissão técnica liderada por pesquisadores do Instituto Nacional de Pesquisas Espaciais (Inpe) e do Centro Técnico Aeroespacial (CTA) de São José dos Campos, para definir uma especificação de requisitos funcionais. A urna eletrônica foi desenvolvida em 1995 e utilizada pela primeira vez nas eleições municipais de 1996.

Surgiram grandes indagaçóes sobre a utilização dessa tecnologia ao longo dos anos. Para dar mais transparência ao voto, nasceu o voto impresso, previsto pela Lei n. 10.408/2002 e, efetivamente, instituído pelo TSE, todavia a Lei n. 10.740/2003 o substituiu por registro digital de voto. Por sua vez, a Lei n. 12.034/2009 novamente instituiu o voto impresso, a qual foi declarada inconstitucional pelo Supremo Tribunal Federal no julgamento da ação direta de inconstitucionalidade n. 4543 ajuizada pela Procuradoria Geral da República.

É nesse contexto que se fará uma sucinta análise da Justiça Eleitoral, passando pela discussão dos princípios do Direito Eleitoral, culminando com abordagem do risco a alguns direitos fundamentais com a utilização do modelo atual de urnas eletrônicas e, ainda, a realização das eleiçóes sob a tutela da Justiça Eleitoral, sob a teoria filosófica/sociológica de Jean Pierre Dupuy e Hans Jonas.

\section{PRINCÍPIOS FUNDAMENTAIS DO DIREITO ELEITORAL}

São vários os princípios do Direito Eleitoral, todavia, nesse momento, abordar-se-ão somente os da democracia, do sufrágio universal e liberdade partidária.

José Jairo Gomes destaca os seguintes princípios: ${ }^{3}$

${ }_{3}$ GOMES, José Jairo. Direito Eleitoral. 3. ed. Belo Horizonte: Del Rey, 2010. p. 29. 
Vários são os princípios presentes no Direito Eleitoral. Entre eles, destacam-se os seguintes: democracia, democracia partidária, Estado Democrático de Direito, poder soberano, republicano, federativo, sufrágio universal, legitimidade, moralidade, probidade, igualdade ou isonomia. Relevam ainda princípios de natureza processual.

\subsection{Princípios da Democracia e República}

A democracia aperfeiçoa-se por meio de contrato social em que o próprio povo soberano se governa. A democracia, como regime, atinge seu ápice quando se dá liberdade plena aos cidadãos, os quais têm direito de participação em igualdade nas atividades políticas do Estado. A respeito da democracia, José Jairo Gomes acentua o seguinte: ${ }^{4}$

Embora práticas democráticas tenham sido experimentadas por vários povos, historicamente aponta-se a Grécia como o berço da democracia. Foram os gregos que cunharam esse termo, que deriva de demokration: demos, povo, e Kratos, poder, ou seja, poder do povo. Entretanto, há notáveis diferenças entre as idéias antiga e contemporânea de democracia. Basta dizer que, na antiguidade, o povo era formado por poucas pessoas e o sufrágio não era universal.

Mais que princípio inscrito na Lei Magna, a democracia constitui fundamento e valor essencial das sociedades ocidentais, definindo sua estética, o modo como elas existem e operam. Tanto é que o artigo XXI da Declaração Universal dos Direitos do Homem, de 1948, e o artigo 25 do Pacto Internacional sobre Direitos Civis e Políticos, de 1966, elevaram-na ao status de direitos humanos. Note-se, porém, que, a despeito da previsão formal em diplomas normativos, a democracia não é algo fixo, pois encontra-se em permanente construção; para muitos pensadores políticos, cuida-se de ideal a ser alcançado. Como ideal, a busca constante de sua concretização exige a efetiva participação de todos os integrantes da comunhão social.

${ }^{4}$ GOMES, José Jairo. Direito Eleitoral. 3. ed. Belo Horizonte: Del Rey, 2010. p. 29. 
Trata-se de um dos mais preciosos valores da atualidade. Os valores são construídos historicamente. Com o tempo, a realização de certas idéias torna-se consenso na comunidade, passando a moldar-lhe o perfil, integrando, pois, seu acervo cultural, sua história. Daí em diante, transformam-se em referências importantes para a tomada de decisóes, e mesmo para a subsistência daquele modelo de vida social. Impóem-se naturalmente, de maneira a moldar a estrutura e o pensamento político da sociedade, participando de sua própria identidade, de seu modo de ser.

Naturalmente os cidadãos em sua totalidade não poderiam participar das decisóes políticas, por isso idealizou-se a representatividade como forma de os cidadãos participarem das atividades políticas. Para que isso ocorra devem eleger seus mandatários para atuarem em seu nome perante o Estado.

A democracia vive em total mutação, modificando-se de acordo com a identidade da sociedade em cada época. As ideias de liberdade e igualdade, sustentáculo da democracia, tomam formas diferentes de acordo com a maturidade da sociedade. Atualmente todos podem participar da vida política do Estado, independentemente de riquezas, sexo ou cor. Isso quer dizer que o sufrágio é universal. Para uma real concretização dos ideais democráticos todos devem participar efetivamente do processo político, sob pena de se criar dissensóes em minorias desrespeitadas e possibilitar uma tentativa de ruptura do contrato social.

Ensina José Jairo Gomes a respeito dessa participação que o sufrágio, ${ }^{5}$

na seara jurídica, designa o direito público subjetivo democrático, pelo qual um conjunto de pessoas - o povo - é admitido a participar da vida política da sociedade, escolhendo os governantes ou sendo escolhido para governar e, assim, conduzir o Estado. Em suma: o sufrágio traduz o direito de votar e de ser votado, encontrando-se entrelaçado ao exercício da soberania popular. Trata-se do poder de decidir sobre o destino da comunidade, os rumos do governo, a condução da Administração Pública.

5 GOMES, José Jairo. Direito Eleitoral. 3. ed. Belo Horizonte: Del Rey, 2010. p. 39. 
Bandeira, por sua vez, acentua que: ${ }^{6}$

A Democracia moderna parece ter encontrado um novo fundamento nos Direitos Humanos universais, além do sufrágio universal.

[...] Ora, se assim é, então a "pedra filosofal" da Democracia embrenha-se na complexidade da Legislação moderna e na problemática da própria Democracia que aqui abordamos, não a resolvendo de modo nenhum - antes, inclina-nos para um problema que é, afinal, uma petição de princípio, uma vez que deparamos com o problema embrulhado, depois de o começarmos a desembrulhar. Os Direitos Humanos só resolverão a questão na forma de uma aculturação, a qual demora muito mais tempo do que as emissóes de declaraçóes ou as seduçóes eleitorais. E precisam de um tecido de posiçóes jurídicas em que os direitos não têm, nem podem ter, qualquer preeminência ontológica. Na realidade, os direitos são finalidades e os meios para os realizar variam de muitas formas, não sendo o Estado e a legislação as únicas existentes.

\section{Carvalho também declara que: ${ }^{7}$}

[..] a democracia é concebida sobretudo como um regime político, pois, sendo o governo do povo, pelo povo e para o povo, que o exerce direta e indiretamente, expressa um estilo de vida política e se converte numa filosofia de vida que se institucionaliza politicamente no Estado, como forma de convivência social. [...]. Para Zorrilla de San Martin, a democracia não é uma forma ou acidente, um fenômeno, mas algo assim como uma substância, uma forma substancial, melhor dizendo, um espírito que, unido ao corpo social, o anima e o especifica. A democracia não é outra coisa que o respeito absoluto à pessoa humana, com todos os seus atributos essenciais: destino próprio inalienável, liberdade para realizá-lo, dignidade, igualdade perante a Justiça e a lei.

A democracia, segundo esclarece Rober A. Dahl, para que seja alcançada e vivenciada, acha-se relacionada com a existência dos elementos seguintes:

${ }^{6}$ BANDEIRA, André. Os limites da democracia - a influência do Direito Democrático europeu e uma nova guerra. Revista do Instituto dos Advogados de Minas Gerais, Belo Horizonte: IAMG, n. 1, p. 201, 1995.

7 CARVALHO, Kildare Gonçalves. Direito Constitucional. 10. ed. rev., atual., e ampl. Belo Horizonte: Del Rey, 2004. p. 126-127. 

a) liberdade para constituir e integrar-se em organiçóes;
b) liberdade de expressão;
c) direito de voto;
d) acesso a cargos públicos;
e) possibilidade de os líderes políticos competirem por meio da votação;
f) fontes alternativas de informação;
g) eleiçóes livres e isentas;
h) existência de instituições capazes de viabilizar a política do governo e legiti- madas pelo voto ou outras manifestaçóes da vontade popular. $[\ldots]$.

Por sua vez, a república é uma forma de governar que afirma e defende a soberania do povo perante o Estado por meio do império da lei. Essa lei, nos Estados Democráticos de Direito, toma a forma de uma Constituição, que traz em seu bojo os direitos e deveres dos cidadãos, e projeta as instituições, garantindo a temporalidade dos mandatos de todos os governantes. Assim, podemos concluir que na república é imprescindível a previsão de igualdade de todos perante a lei e a anterior definição das regras a serem cumpridas pelos cidadãos e pelos governantes, como forma de conter seus anseios particulares e garantir-se que ninguém estará acima da lei.

José Jairo Gomes assim discorre sobre o tema: ${ }^{8}$

As formas de governo relacionam-se à estruturação do Estado com vistas ao exercício do poder. Em outros termos, dizem respeito ao modo de atribuição do poder político-estatal.

Atualmente, duas são as formas de governo mais difundidas: monarquia e república. Aquela tem como características a hereditariedade e a vitaliciedade do chefe do Estado. Não há, pois, rotatividade no exercício do poder. Diferentemente, a república tem por fundamentos a eletividade, a temporalidade e a alternância de pessoas no comando do Estado.

${ }_{8}^{8}$ GOMES, José Jairo. Direito eleitoral. 3. ed. Belo Horizonte: Del Rey, 2010. p. 37. 
$\mathrm{Na}$ forma republicana de governo, tanto o chefe do poder Executivo quanto os membros do Legislativo cumprem mandato, sendo diretamente escolhidos pelos cidadãos em eleições diretas, gerais e periódicas. Trata-se, pois, de governo representativo.

Sem perder de vista que existem monarquias liberais, tal qual a da Inglaterra, que alcançam o ideal de liberdade dos cidadãos mais efetivamente que alguns Estados que têm uma roupagem de república, mas no fundo não passam de uma ditadura.

Entendemos, no entanto, que a democracia sob a forma republicana é mais eficaz e executa melhor os ditames da igualdade, liberdade, representatividade, etc., inclusive a proteção das minorias ocorre com efetividade na democracia republicana.

Carvalho assinala a característica da república com forma de democracia: ${ }^{9}$

Não obstante, a Constituição de 1988, ao instituir a República Federativa do Brasil como Estado Democrático de Direito (art. $1^{\circ}$ ), vincula essa forma de governo à idéia de democracia e, portanto, de um governo limitado e responsável, surgindo daí a idéia de responsabilidade da Administraçáo Pública, presente no artigo 37, artigo 93, IX, e no princípio do artigo 70, parágrafo único, segundo o qual "prestará contas qualquer pessoa física ou entidade pública que utilize, arrecade, guarde, gerencie ou administre dinheiros, bens e valores públicos ou pelos quais a União responda, ou que, em nome desta, assuma obrigaçóes de natureza pecuniária”.

A democracia aperfeiçoa-se por meio de contrato social em que o próprio povo soberano se governa. Como regime, atinge seu ápice quando se dá liberdade plena aos cidadãos, os quais têm direito de participação em igualdade nas atividades políticas do Estado, não importando o sexo, cor, condiçóes financeiras, etc. $\mathrm{O}$ sufrágio é universal.

Destarte, não se deve defender que na democracia a vontade da maioria deve prevalecer em todas as situaçóes. Entende-se que deve ser realizada não somente a vontade da maioria, mas também a vontade de todos, inclusive das minorias, pois

9 CARVALHO, Kildare Gonçalves. Direito Constitucional. 10. ed., rev., atual., e ampl. Belo Horizonte: Del Rey, 2004. p. 343. 
caso assim não fosse, poderia haver um desequilíbrio na sociedade, o que é perigoso para a democracia, com consequências que podem ir até a quebra do contrato social. A participação política de todos é essencial ao bom andamento da democracia.

Bandeira observa que: ${ }^{10}$

Ora, a Democracia moderna tem uma definição transcendente e outra, imanente.

A primeira assenta-se no fato de que o que legitima a Democracia é - à semelhança de certas tendências no pensamento científico ocidental contemporâneo e da chamada "Ciência popular" - um conjunto de conteúdos indefinidamente extensíveis quanto às regras da sua legitimação. Basicamente, o Parlamento e as "constituencies" podem constituir o que quiserem, até transformarem um homem em mulher e vice-versa. [...].

Quer dizer, a constante tendência a ser-se julgado sem lei, ou seja, gerir constantemente a crise da democracia num tom de julgamento, quando a lei varia ao sabor das maiorias, comandadas por elites oportunas que vão ministrando alívios e disseminando angústias, é o mesmo que não ter lei, mas, não obstante, é estar sempre a ser julgado. É um lugar para super-homens, um imenso campo de concentraçâo como o do "juiz-penitente" que narra "A Queda”. Ele refugia-se da afliçâo diária, num bar de má pinta em Amesterdá, onde é vencido pelo mal de viver, afinal a sua total impotência, e acaba se suicidando. Se ele é um super-homem, pela sua consciência desapaixonada, também não se consegue libertar da sua liberdade julgadora. Nem se absolve, nem expia.

Por isso, um governo democrático é aquele que concilia a opinião de todos os grupos sociais, mormente os minoritários, permitindo-lhes participar também efetivamente das decisóes do Estado.

${ }^{10}$ BANDEIRA, André. Os limites da democracia - a influência do Direito Democrático europeu e uma nova guerra. Revista do Instituto dos Advogados de Minas Gerais, Belo Horizonte: IAMG, n. 1, p. 195-196, 1995. 


\subsection{Princípios do Sufrágio Universal e Voto Obrigatório}

Sufrágio universal não se confunde com voto. $\mathrm{O}$ conceito de sufrágio é muito mais abrangente que o de voto. O sufrágio está previsto no artigo 14 da Constituição da República:

Art. 14. A soberania popular será exercida pelo sufrágio universal e pelo voto direto e secreto, com valor igual para todos, e, nos termos da lei, mediante: [...]

José Jairo Gomes" acentua que: "Sufrágio e voto não se confundem. Enquanto sufrágio é um direito, o voto representa seu exercício. Em outras palavras, o voto é a concretização do sufrágio."

Carvalho igualmente esclarece a diferença entre sufrágio e voto: ${ }^{12}$

O sufrágio é universal, isto é, o direito de votar e se ser votado é conferido a todos os cidadáos, independentemente de qualquer distinçáo quanto, por exemplo, a sexo, classe social ou econômica, mas que atendam às condiçóes indicadas genéricas e abstratamente no texto constitucional, relativas à nacionalidade, capacidade, idade e alistamento eleitoral, que, no entanto, não desqualificam o sufrágio como universal, desde que sejam prévia, genérica e abstratamente definidos e aplicáveis a todos os cidadãos. O voto é direto, ou seja, a escolha se faz sem a figura de eleitores intermediários. O escrutinio é secreto, pois com isso se procura resguardar a autenticidade da manifestaçáo do eleitor, garantindo o sigilo da votação, por meio de mecanismos previstos na lei eleitoral, tais como cédula oficial entregue ao eleitor no momento da votaçáo, recolhimento deste à cabine indevassável para o exercício do voto, depósito da cédula da urna, mostrando antes a parte externa rubricada para comprovação de que não houve substituição fraudulenta. A introdução, no processo eleitoral, da urna eletrônica, reforça ainda mais a garantia do sigilo da votação.

${ }^{11}$ GOMES, José Jairo. Direito eleitoral. 3. ed. Belo Horizonte: Del Rey, 2010. p. 43.

${ }^{12}$ CARVALHO, Kildare Gonçalves. Direito Constitucional. 10 ed. rev. atual., e ampl. Belo Horizonte: Del Rey, 2004. p. 462-463. 
Quanto ao voto, Gomes assevera que: ${ }^{13}$

O voto é um dos mais importantes instrumentos democráticos, pois enseja o exercício da soberania popular e do sufrágio. Cuida-se do ato pelo qual os cidadãos escolhem os ocupantes dos cargos político-eletivos. Por ele, concretiza-se o processo de manifestação da vontade popular.

Embora expresse um direito público subjetivo, o voto é também um dever cívico e, por isso, é obrigatório para os maiores de 18 anos e menores de 70 anos (CF, art. $14, \$ 1^{\circ}$ ). Sua natureza jurídica deve ser bem explicitada, pois, consoante adverte Ferreira (1989:295), ele "é essencialmente um direito público subjetivo, é uma função da soberania popular na democracia representativa e na democracia mista como um instrumento deste, e tal funçáo social justifica e legitima a sua imposição como um dever, posto que o cidadão tem o dever de manifestar sua vontade na democracia”. Argumenta-se, ainda, que a obrigatoriedade do voto faz que o cidadão se interesse mais pela vida política, dela se aproximando, e que a "massa popular" não é preparada para o voto facultativo.

Como é possível constatar, o sufrágio universal é um direito fundamental previsto na Constituição como forma de preservar o Estado Democrático de Direito. Não existe democracia sem que se dê direito ao cidadão de escolher seus representantes e também de participar da vida política do país. Por isso, o voto corresponde ao exercício do sufrágio, é a reverberação do direito de participaçáo na sociedade, quer como cidadáo votante, quer como candidato a cargo político.

\subsection{Princípio da Liberdade Partidária}

Os partidos políticos são de suma importância na democracia representativa, sem dúvida. Essas entidades canalizam os anseios da sociedade fazendo-os chegar à Câmara dos Deputados e ao Senado da República. A voz do povo se faz sentir por intermédio dos partidos políticos que detêm o mandato dos representantes do povo.

${ }^{13}$ GOMES, José Jairo. Direito Eleitoral. 3. ed. Belo Horizonte: Del Rey, 2010. p. 43. 
A respeito da essencialidade dos partidos políticos José Jairo Gomes acentua: ${ }^{14}$

No mundo contemporâneo, os partidos políticos tornaram-se peças essenciais para o funcionamento do complexo mecanismo democrático. Para se ter noção da penetração e influência dessas entidades, basta dizer que detêm o monopólio do sistema eleitoral, chegando a definir o perfil assumido pelo Estado. Não há, com efeito, representação popular e exercício do poder estatal sem a intermediação partidária.

Tais entidades constituem canais legítimos de atuação política e social; captam e assimilam rapidamente a opinião pública; catalisam, organizam e transformam em bandeiras de luta as díspares aspiraçóes surgidas no meio social, sem que isso implique ruptura no funcionamento do governo legitimamente constituído. Ressalta Caggiano (2044:105) que, "no mundo atual, assume o partido posição fortalecida de mecanismo de comunicação e de participação do processo decisional; mais até, de instrumento destinado ao recrutamento dos governantes e à socialização política”. Não é exagero supor que a normalidade democrática depende da existência de tais "mecanismos de comunicação e de participação". A ausência deles pode induzir uma resposta violenta de setores da sociedade que se sentirem prejudicados e excluídos.

Deve-se, todavia, fazer uma crítica ao pluralismo político ou ao sistema multipartidário, fundamento da República Federativa do Brasil, que vigora quando existem três ou mais partidos políticos em um Estado, sendo ponto crucial a natureza democrática, ou seja, a existência de vários grupos díspares, com a consequente participação efetiva da minoria.

A pulverização partidária pode ser um ponto de enfraquecimento, uma vez que o número excessivo de partidos conduz à dissipação do poder e a um desequilíbrio interna corporis. Pode ocorrer o domínio de partidos pequenos e fracos pelo poder Executivo de forma a cortar a participaçáo efetiva desses partidos.

${ }^{14}$ GOMES, José Jairo. Direito Eleitoral. 3. ed. Belo Horizonte: Del Rey, 2010. p. 80. 
O sistema de representação proporcional permite retratar, no parlamento, as diversas opinióes distribuídas no corpo do país. Assim, até as correntes de pensamento minoritárias, mediante a adoção do referido sistema, podem, eventualmente, garantir uma vaga no Legislativo.

Esse último aspecto é uma das virtudes do sistema proporcional, pois, ao contrário do sistema majoritário, possibilita a representação das minorias. Outro ponto positivo é o estímulo à criação de novos partidos políticos, essencialmente em virtude de sua natureza maleável e aberta a novas correntes ideológicas, o que favorece, dessa forma, o pluralismo político.

O sistema garante um cenário político mais compatível com a sociedade democrática de cada época, pois permite englobar diversos grupos de interesses nas instituiçóes políticas.

A variedade de partidos políticos leva a um enfraquecimento e à instabilidade dos governos. O sistema proporcional também estimula a formação de alianças e coligaçóes de partidos que sequer possuem compatibilidade entre si, burlando a expectativa dos eleitores em serem atendidos em suas ideologias. As formas complicadas de contagem de votos para se conseguir uma cadeira no parlamento é um ponto negativo, uma vez que o eleitor, na maioria das vezes, não conhece bem esse sistema, essa forma de cálculo, e não entende como um candidato com menos votos pode ser eleito.

A respeito da liberdade partidária, Amaral e Cunha ensinam que: ${ }^{15}$

O princípio da liberdade partidária, indiscutivelmente, posto pela Constituição, vincula-se ao princípio pluralista. Por quatro vezes a lei fundamental utiliza o termo "pluralismo": em seu preâmbulo (pluralismo social), no art. $1^{\circ}$ (pluralismo político), no art. 17 (pluralismo partidário), e no art. 206-III (pluralismo de idéias e concepçóes pedagógicas). Esse não é, certamente, um termo vazio. Ao contrário, possui uma significação prescritiva, qualitativa. Dizer que uma sociedade deve ser pluralista não significa fixar-se uma determinaçáo numérica, acima de alguns e abaixo de muitos, dentro da qual se permite a convivência dos diferentes. Significa, ao contrário, o dever de criar e manter esse espaço de

${ }^{15}$ AMARAL, Roberto; CUNHA, Sérgio Sérvulo. Manual das eleiçōes. São Paulo: Saraiva, 2006. p. 671. 
convivência; restringi-lo, direta ou indiretamente, corresponde a ferir o princípio pluralista. Pluralismo, instrumentação da liberdade, tem sentido mais concreto, mais preciso do que esta.

O artigo 17, I, da Constituição Federal, preceitua que é livre a criação, fusão, incorporação e extinção de partidos políticos, observado o seu caráter nacional. Tal dispositivo constitucional - por mais que não tenha especificado o alcance da expressão caráter nacional - é autoaplicável, tendo em vista que não prevê a necessidade de regulamentação por lei ordinária.

Em que pese ser dispensável a regulamentação deste artigo, pois a plena liberdade de criação dos partidos políticos é uma garantia constitucional, o Congresso Nacional editou a Lei n. 9.096/95 - Lei dos Partidos Políticos - exigindo a criação em sua estrutura de ramificaçóes organizacionais espalhadas em Estados federativos distintos:

Art. $7^{\circ} \mathrm{O}$ partido político, após adquirir personalidade jurídica na forma da lei civil, registra seu estatuto no Tribunal Superior Eleitoral.

$\$ 1^{\circ}$ Só é admitido o registro do estatuto de partido político que tenha caráter nacional, considerando-se como tal aquele que comprove o apoiamento de eleitores correspondente a, pelo menos, meio por cento dos votos dados na última eleição geral para a Câmara dos Deputados, não computados os votos em branco e os nulos, distribuídos por um terço, ou mais, dos Estados, com um mínimo de um décimo por cento do eleitorado que haja votado em cada um deles.

Extrai-se do dispositivo citado que o legislador ordinário impôs um novo requisito para o registro do estatuto do partido não previsto no texto constitucional

Assim, a Carta Magna ao prever o caráter nacional dos partidos quis impedir programas político-partidários com propostas locais ou regionais e não a necessidade de apoio de determinado número de eleitores, distribuídos por unidades da Federação. 
Por tais razóes, o artigo $7^{\circ}, \$ 1^{\circ}$ da Lei dos Partidos Políticos vulnera profundamente o princípio constitucional que assegura a plena liberdade de criação dos partidos políticos, nos termos do artigo 17 da Constituição Federal, pois o legislador ordinário cria, a seu alvedrio, uma nova "cláusula de barreira". O STF, contudo, já se posicionou pela constitucionalidade da Lei dos Partidos Políticos.

\section{PROCESSO ELETRÔNICO DE VOTAÇÃO}

Antes do voto eletrônico o cidadão votava em cédulas de papel e as depositava em uma urna de lona. Isso durou até 1996, quando foi adotado o processo eletrônico de voto.

O processo eletrônico entrou no cenário brasileiro para dar maior transparência e agilidade ao voto do cidadão e, mais importante, mais segurança na votação, evitando as fraudes eleitorais que eram táo comuns antes de voto eletrônico.

Segundo o site do Tribunal Superior Eleitoral, os estudos para instalação das urnas eletrônicas iniciaram-se em 1995 e, em 2014, 115 milhōes de brasileiros votaram dessa forma. ${ }^{16}$

Em 1996, um ano depois do protótipo ter sido apresentado ao TSE, mais de 32 milhóes de brasileiros, um terço do eleitorado da época, foram votar nas mais de 70 mil urnas eletrônicas produzidas para aquelas eleiçôes. Participaram 57 cidades com mais de 200 mil eleitores, entre elas, 26 capitais.

Já nas eleiçôes de 1998, a votaçáo eletrônica ocorreu em 537 municípios brasileiros com mais de 40.000 eleitores, correspondendo a $75 \%$ do eleitorado nacional da época. Contudo, somente no pleito de 2000 é que a votação eletrônica foi utilizada em todos os municípios brasileiros, tendo sido, portanto, completamente informatizada.

\footnotetext{
${ }^{16}$ http://www.tse.jus.br/imprensa/noticias-tse/2016/Janeiro/serie-urna-eletronica-conheca-a-historiada-informatizacao-do-voto-no-brasil Acesso em: 21.07. 2017.
} 
Nas eleiçóes de 2008, foram testadas as primeiras urnas eletrônicas com leitores biométricos nos municípios de São João Batista (Santa Catarina), Fátima do Sul (Mato Grosso do Sul) e Colorado do Oeste (Rondônia). Depois do sucesso da revisão biométrica nas três cidades, a Justiça Eleitoral decidiu dar continuidade, em 2010, ao projeto de identificação biométrica do eleitor em outros 57 municípios. Dessa forma, nas eleições gerais daquele ano, 1,1 milhão de eleitores de 60 municípios de 23 estados votaram após serem identificados pela tecnologia da biometria.

Em 2012, ano de eleiçóes municipais, a identificação biométrica na urna eletrônica foi realizada em 24 estados, 299 municípios e atingiu mais de 8 milhóes de eleitores que já estavam aptos a serem identificados por meio da impressão digital.

Eleições 2014

Considerada a maior de todos os tempos, as Eleiçóes Gerais de 2014 utilizaram quase meio milháo de urnas para registrar o voto dos 115 milhóes de brasileiros que compareceram ao pleito. No primeiro turno, o tempo de apuração e totalização de votos foi recorde: às $19 \mathrm{~h} 56 \mathrm{~m} 28 \mathrm{~s}$ já era possível saber o resultado matemático, com $91 \%$ dos votos válidos apurados.

A biometria também ganhou maior dimensão e foi utilizada por mais brasileiros. Cerca de 21 milhóes de cidadãos de 764 municípios de todos os estados e do Distrito Federal estiveram aptos a serem identificados por meio do leitor biométrico. E a identificaçáo das digitais dos eleitores apresentou alto índice de efetividade.

De acordo com o secretário de TI, a urna eletrônica, apesar de não ter sofrido alteraçóes significativas em seu exterior de uns anos para cá, está em constante evolução interna para garantia da segurança. A urna atual tem $15 \mathrm{~cm}$ de altura, 27 de profundidade, $42 \mathrm{~cm}$ de largura e pesa $8 \mathrm{~kg}$.

De acordo com o mesmo site, foram levadas em conta as principais premissas para a utilização das urnas eletrônicas: ${ }^{17}$

${ }^{17}$ BRASIL. Informatização da JE. Histórico. Infraestrutura e logística. Avaliação do sistema. Disponível em: <http://www.tse.jus.br/eleicoes/biometria-e-urna-eletronica/eleicoes>. Acesso em: 20 dez. 2013. 
1. Soluçáo universal - registro do voto pelo número do candidato ou partido;

2. Aderência à legislação de vigente, com possibilidade de evolução para garantir que mudanças na legislação eleitoral não obrigassem a alteraçóes na urna eletrônica;

3. Processo amigável, de fácil utilização pelo eleitor, com a visualização na tela dos dados do candidato antes da confirmação do voto;

4. Custo reduzido - o projeto deveria ser economicamente viável, em função do elevado número de seçôes eleitorais;

5. Perenidade - possibilidade de uso em várias eleiçóes, diminuindo o custo do voto;

6. Segurança - eliminação da possibilidade de fraude no registro do voto e apuração do resultado;

7. Facilidade na logística - pequena, rústica, peso reduzido, de fácil armazenamento e transporte;

8. Autonomia - uso de bateria nos locais onde não há energia elétrica.

Segundo o TSE (item 6) a segurança consiste na eliminação da possibilidade de fraude no registro do voto e na apuração do resultado, todavia o direito do cidadão em ter ciência se seu voto foi realmente computado para o candidato em quem ele votou não foi objeto de discussão.

\section{A EXCLUSÃO dO ELEITOR NA FISCALIZAÇÃO DE SEU PRÓPRIO VOTO}

Os direitos políticos insculpidos na Constituição da República, segundo Lobo, "cuidam da participação dos cidadãos na gestão dos negócios do Estado. São direitos que interferem em outros porque a garantia deles confere legitimidade à produção legislativa, à gestão administrativa e à função jurisdicional. "I8

${ }^{18}$ LOBO. Edilene. A inclusão do cidadão no processo eleitoral. Belo Horizonte: Del Rey, 2010. p. 115. 
O eleitor, todavia, tem sido excluído de todo o processo eleitoral, apenas tem o direito de votar e nada mais. A Jurisprudência do Tribunal Superior Eleitoral, a Lei 9.504/97 e a Lei Complementar n. 64/90 afastam a participaçáo do cidadão em todo o processo eleitoral. Nas palavras de Gresta, Ferreira e Bracarense: ${ }^{19}$

\begin{abstract}
Quanto ao recurso contra expedição de diploma (RCED) e à ação de impugnaçáo de mandato eletivo (Aime), incumbiu-se a jurisprudência de suprir a ausência de previsão legal do rol de legitimados para sua propositura. Consolidou-se, a partir de decisōes reiteradas do TSE, o entendimento de que "não têm legitimidade ad causam os apenas eleitores" (BRASIL, 1994). Na decisão na qual se firmou a posição de que o sistema infraconstitucional não contempla a participação do cidadão no processo eleitoral jurisdicional, afirmou-se que o reconhecimento da legitimidade para agir dos eleitores afrontava, entre outros dispositivos, o art. $3^{\circ}$ do Código de Processo Civil, que determina a necessidade de interesse e legitimidade para a propositura da ação. A partir dessa posição, estabeleceu-se a interpretação de que os legitimados ativos para a propositura dessas ações seriam os mesmos elencados no art. 22 da Lei Complementar n. 64/90.
\end{abstract}

A negativa estatal de reconhecimento do interesse do cidadáo no processo eleitoral, seja pela via legal ou pela jurisprudencial, choca-se com o princípio democrático. O povo é considerado como entidade abstrata que se sobrepõe aos indivíduos que o compóem, bem como o abstrato interesse geral é dissociado de qualquer interesse individual. Maciel Junior (2006, p. 60-61) alerta para o perigo dessa formulação, que coloca nas mãos de interlocutores autorizados a prerrogativa de, a partir de sua própria percepção, definir o sentido do que seja o interesse de toda a coletividade.

As resoluçóes, por sua vez, repetem as leis no sentido de afastar qualquer legitimidade do cidadáo no processo eleitoral, sendo certo que somente os partidos políticos, candidatos e Ministério Público Eleitoral têm legitimidade para questionar quaisquer irregularidades ou fraudes no processo eleitoral.

${ }^{19}$ GRESTA, Roberta Maia; FERREIRA, Lara Marina; BRACARENSE, Mariana Sousa. Coletânea de artigos jurídicos NAP 2011. Igor Alves Noberto Soares et al. (Org.). Parâmetros de legitimidade da atuação dos partidos políticos no processo jurisdicional eleitoral. 1. ed. Curitiba, PR: CRV, 2012. p. 235. 
A exclusão do cidadão da fiscalização das atividades administrativas ou jurisdicionais é completamente inconstitucional, mormente, como asseverado anteriormente, o princípio democrático. Sem dúvidas, a Constituição dá legitimidade ao povo para fiscalizar diretamente a coisa pública e as eleiçôes não são exceção.

Edilene Lobo também pontua que: ${ }^{20}$<smiles>[AlH2]</smiles>

Transpondo esse raciocínio para o processo eleitoral, se for atingido o direito político, logicamente será afetado o interesse do eleitor e de toda a coletividade. Desse modo, tanto o cidadáo como as entidades variadas envolvidas nos pleitos são legitimados para o manejo de açóes que visam sindicar a corrupção eleitoral, o abuso de poder econômico, a propaganda abusiva, porquanto condutas desnaturadas da liberdade do voto, da legitimidade e do equilíbrio.

Embora o raciocínio das autoras citadas diga respeito à legitimidade do eleitor para propor açóes judiciais, o mesmo raciocínio pode ser utilizado para que o eleitor possa fiscalizar o ato de votar, fiscalizar se seu voto realmente foi computado para o candidato em quem votou, mas isso não ocorre. Como se sabe, o cidadão não tem legitimidade para defender a democracia nem tem direito de saber se seu voto foi computado corretamente.

Nesse ponto, há grandes indagaçóes a respeito da observância dos princípios constitucionais pelo Tribunal Superior Eleitoral, uma vez que, pelo menos, os princípios democráticos e da publicidade, após a utilização das urnas eletrônicas, ficaram comprometidos e, segundo o relatório do Comitê Multidisciplinar Independente, "com essa abordagem da autoridade eleitoral brasileira, a importância do

${ }^{20}$ LOBO, Edilene. A inclusão do cidadão no processo eleitoral. Belo Horizonte: Del Rey, 2010. p. 130. 
eleitor fica restrita à obrigação de comparecer, identificar-se, votar e acreditar que seu voto foi mesmo registrado e computado, pois daí em diante vale táo somente o que o resultado eletrônico indicar." ${ }^{21}$

\section{RISCO DA TECNOLOGIA MANUSEADA POR UM PODER INAPTO SUPLANTAR DIREITOS FUNDAMENTAIS}

O surgimento das urnas eletrônicas está umbilicalmente associado à era tecnológica. A respeito da tecnologia, Lucas Abreu Barroso pontua: ${ }^{22}$

${ }^{21}$ COMITÊ MULTIDISCIPLINAR INDEPENDENTE. Relatório sobre o sistema brasileiro de votação eletrônica. http://www.brunazo.eng.br/voto-e/textos/RelatorioCMind.pdf. Acesso em 22 de dezembro de 2013. In: O Princípio da Publicidade no processo eleitoral era perfeitamente atendido no sistema de votaçáo manual. O eleitor via o conteúdo do Registro do Voto - a cédula eleitoral - antes de ser colocada na urna. Na apuração, todos esses Registros do Voto eram abertos para serem vistos e contados perante os representantes dos candidatos. Porém, com a adoção das máquinas DRE no Brasil em 1996, o Princípio da Publicidade no processo eleitoral eletrônico teve seu alcance restringido. Como ressaltado pelo Tribunal alemão nos Fundamentos 155 e 156, o eleitor não tem como ver ou conferir o que foi gravado no Registro Digital do Voto, porque essa gravação só ocorre depois que ele encerra sua participação ao digitar a tecla Confirma e, assim, nunca terá como saber se o $R D V$ teria registrado o seu voto conforme digitado. Além disso, o resultado da apuração - o Boletim de Urna -é calculado e oficialmente publicado sem que os fiscais dos candidatos possam antes ver cada $R D V$ para conferi-los e contá-los. O CMTSE posiciona-se em direção contrária ao Princípio da Publicidade e desconsidera o direito do cidadão médio de entender e fiscalizar o processo, defendendo soluçóes tecnológicas mesmo que não compreendidas pelo cidadão comum, como em suas consideraçốes finais na Seçâo 4.3, "verbis":

O fato de que o uso de criptografia e mecanismos sofisticados tecnologicamente não serem entendidos pela maioria dos eleitores, candidatos e público em geral, não diminui os benefícios que essas ferramentas modernas trazem para a segurança das eleiçôes.

Essa tese esposada pelo CMTSE reflete o posicionamento de seu coordenador e da própria Justiça Eleitoral. Vem crescendo como linha diretriz da autoridade eleitoral nas seis últimas eleiçóes desde a adoção das urnas eletrônicas. Suas normatizaçôes têm seguido uma tendência constante de desconsideração desses direitos constitucionais dos eleitores. O argumento do CMTSE repete esse entendimento, mas fere de morte o princípio de publicidade e os direitos contidos no Artigo 14 da Constituiçáo Federal, pois distancia-se da supremacia do direito do eleitor em ver, de forma a si compreensível, a sua vontade preservada tanto no ato de votar quanto na destinação dada a seu voto, posto que é no final do processo que o voto preencherá os requisitos de eficácia, atributo essencial da obediência à vontade popular. Com essa abordagem da autoridade eleitoral brasileira, a importância do eleitor fica restrita à obrigação de comparecer, identificar-se, votar e acreditar que seu voto foi mesmo registrado e computado, pois daí em diante vale táo somente o que o resultado eletrônico indicar.

${ }^{22}$ BARROSO, Lucas Abreu. A obrigaçāo de indenizar e a determinação da responsabilidade civil por dano ambiental. Rio de Janeiro: Forense, 2006, p. 12-13. 
Todavia, em menos de dois séculos ruía a sociedade industrial e se estava adentrando na atual fase do progresso técnico, a denominada etapa científica ou era tecnológica, na qual "La nueva riqueza de las naciones está constituída por el know-how o recurso estratégico de la información”.

Uma nova fase de transição da sociedade industrial para outro modelo social e de produção, havia sido delineada em um estágio avançado daquela, e quase podei ser vislumbrada através da manifestação de três fenômenos: a) convergência progressiva entre os países industriais independentemente de seu regime político; b) crescimento das classes médias no âmbito da sociedade e da tecno-estrutura da empresa; c) difusão do consumo de massa e da sociedade de massa.

A questão é saber se essa nova tecnologia utilizada na votação será harmonizada com os direitos e garantias do cidadão, previstos na Constituição Federal, mormente os princípios democráticos e do Estado Democrático de Direito.

Não seria demais vislumbrar, não afirmar, que a técnica poderá suplantar cânones constitucionais, de modo a afastar direitos inalienáveis alcançados a duras penas ao longo do século, se instituída a ferro e fogo, sem espaço para diálogo.

Segundo Dupuy, “inúmeros são os críticos da sociedade moderna que defenderam a ideia de que o desenvolvimento científico e técnico da humanidade constituía um processo autônomo, escapando do domínio dos homens." ${ }^{23}$

E nas palavras de Hans Jonas: ${ }^{24}$

[...] A experiência tem ensinado que os desenvolvimentos tecnológicos postos em marcha pela ação tecnológica com objetivos de curto prazo tendem a se autonomizar, isto é, a adquirir sua própria dinâmica compulsiva, com um crescimento espontâneo graças ao qual, como dissemos, eles se tornam não só irreversíveis como também autopropulsionados, ultrapassando de muito aquilo que os agentes quiseram e planejaram aquilo que já foi iniciado rouba de nossas mãos as rédeas da ação, e os fatos consumados, criados por aquele início, se

${ }^{23}$ DUPUY, Jean-Pierre. O tempo das catástrofes: quando o impossível é uma certeza. São Paulo: É Realizaçóes Editora, 2011. p. 85.

${ }^{24}$ JONAS, Hans. Princípio da responsabilidade: ensaio de uma ética para civilização tecnológica. Rio de Janeiro: Editora PUC Rio, 2016. p. 78. 
acumulam, tornando-se a lei de sua continuação. Na hipótese de que tomemos a nossa própria evolução em nossas mãos, então esta nos escapará exatamente por ter incorporado a si mesma esse impulso. Mais do que em qualquer outra parte, aplica-se aqui o provérbio de que temos liberdade para dar o primeiro passo, mas nos tornamos escravos do segundo e de todos os passos subseqüentes.

A aceleraçáo do processo eletrônico de votação sem que houvesse maiores discussóes, de fato, compromete(u) a legitimidade das eleiçóes, uma vez que são inúmeros os questionamentos em torno da urna eletrônica, sendo certo que o cidadáo tem o direito de ver o conteúdo do voto, a exemplo do que ocorria com a votação com cédula eleitoral que era colocada na urna de lona.

O voto impresso foi previsto pela Lei n. 10.408/2002 e, efetivamente, instituído pelo TSE, todavia a Lei n. 10.740/2003 o substituiu por registro digital de voto.

Por sua vez, a Lei n. 12.034/2009 novamente instituiu o voto impresso, declarada inconstitucional pelo Supremo Tribunal Federal, no julgamento da ação direta de inconstitucionalidade n. 4.543 ajuizada pela Procuradoria Geral da República. Entendeu o STF que o voto impresso contraria a garantia do sigilo do voto previsto na Constituição Federal. Infelizmente foi um retrocesso, pois a impressáo do voto seria prova somente do eleitor. Não se deve tratar o eleitor como irresponsável. O STF confundiu sigilo com meios de prova.

O Tribunal Superior Eleitoral desde o início se colocou contrário ao voto impresso utilizando-se de inúmeros argumentos. No seu site esse Tribunal traz uma explicação sobre o voto impresso. Vejamos: ${ }^{25}$

${ }^{5}$ TRIBUNAL SUPERIOR ELEITORAL. Urna eletrônica. Voto impresso. Disponível em: $<\mathrm{http} / /$ www.tse.jus.br/eleicoes/biometria-e-urna-eletronica/ urna-eletronica>. Acesso em: 20 dez. 2013. 
O voto impresso foi aprovado pelo Congresso Nacional em setembro de 2009, na ocasião da minirreforma eleitoral. De acordo com o texto contido na Lei $\mathrm{n}^{\circ}$ 12.034, a urna eletrônica exibirá as telas referentes aos votos digitados e, após a confirmação do eleitor, a máquina deverá imprimir um número único de identificação do voto associado à sua própria assinatura digital.

A mesma regra também prevê que esse documento impresso seja depositado de forma automática, sem contato manual do eleitor, em local previamente lacrado e, posteriormente, passará por auditoria independente em audiência pública a ser realizada pela Justiça Eleitoral após o fim da votação. O objetivo desse procedimento é comparar o resultado apresentado na urna eletrônica com o resultado dos votos impressos.

\section{Retrocesso}

A Justiça Eleitoral posicionou-se de forma contrária ao voto impresso desde a sançáo da Lei $n^{\circ} 12.034$, por considerar esse procedimento um retrocesso comparado aos tempos de votação manual. Quando o projeto foi aprovado pelo Congresso, o então presidente do TSE, ministro Ayres Britto, chegou a pedir ao presidente da República que vetasse o dispositivo da lei. Na opinião do ministro, não havia sentido ter o voto impresso uma vez que a mesma eficiência de checagem de votos pode ser alcançada por meio eletrônico, dispensando o gasto extra exigido na impressão de votos.

O voto impresso no Brasil ocorreu nas eleiçóes gerais de 2002, conforme o disposto na Lei $\mathrm{n}^{\circ} 10.408 / 2002$, em todas as seçóes eleitorais do Estado de Sergipe, do Distrito Federal e em mais 73 municípios (formato PDF) de todas as unidades da Federação. Cerca de sete milhões de eleitores votaram em urnas com impressão do voto.

O sistema, no entanto, entre outras desvantagens, apresentou um grande número de falhas, impedindo o transcurso fluente dos trabalhos nas seçóes eleitorais. Além disso, os custos de implantação foram muito altos, a demora na votação foi maior que nas seções onde não havia voto impresso, o número de panes foi expressivo nas impressoras e o procedimento na carga dos programas foi mais demorado.

Também houve exigência de envio do material de votação manual para as seções; necessidade de procedimentos de transporte, de guarda e de segurança física das urnas de lona contendo os votos impressos; treinamento complexo para os mesários, contrariando a orientação geral de simplificação do processo 
eleitoral; ao corrigir o voto duas vezes, muitos eleitores se negaram a votar em cédula de papel, retirando-se da seção eleitoral; a porta de conexão do módulo impressor, além de apresentar problemas de conexáo, é uma porta aberta à intrusão e tentativa de fraude.

A Lei $\mathrm{n}^{\circ} 10.740 / 2003$ substituiu o voto impresso pelo registro digital do voto.

A Lei n ${ }^{\circ} 12.034 / 2009$ previu algumas mudanças no sistema eletrônico de votação brasileiro, entre elas o retorno do uso do chamado "voto impresso" já nas eleiçóes de 2014. No entanto, por entender que, entre outros motivos, a impressáo do voto fere o artigo 14 da Constituiçáo Federal, que garante o voto secreto, no dia 19 de setembro de 2011 os ministros do Supremo Tribunal Federal (STF) concederam uma medida cautelar para suspender, até o julgamento de mérito, a aplicação do voto impresso no referido pleito.

A decisão do STF, unânime, ocorreu no julgamento da Ação Direta de Inconstitucionalidade (ADI) 4.543, ajuizada pela Procuradoria Geral da República (PGR).

O Congresso Nacional, representante autêntico do povo, editou a lei n. $12.034 / 2009$ de modo a preservar direitos constitucionais do cidadão, todavia o guardião da Constituição, o STF, composto por 11 ministros, entendeu que o cidadão não tinha direito de ver seu próprio voto, ter uma prova substancial nas mãos. Essa é mais uma questão que se exsurge da composição do TSE, pois, composto também por ministros do STF, as decisóes deste último tendem a ser imparciais, em razão da passagem dos ministros do STF por aquele Tribunal.

Entende-se que é inadmissível a participação de ministros do Supremo Tribunal Federal na composição do Tribunal Superior Eleitoral, eis que os ministros da Suprema Corte que tiverem participado do julgamento no Tribunal Superior Eleitoral irão repetir, no STF, o mesmo voto proferido na instância anterior, vulnerando a parcialidade que deve existir no julgamento de qualquer processo.

O que se tem visto, nos julgamentos de processos oriundos do TSE, é, sempre e sempre, os Ministros do STF, com assento no TSE, repetirem e confirmarem os votos já proferidos na instância inferior, havendo até, de parte de alguns, a exagerada preocupaçáo na defesa da posição antes adotada, como se fora esta 
a correta, intocável e inatingível, ainda que vencedora por maioria escassa de votos. O TSE é instância inferior ao Supremo Tribunal Federal, jamais podendo abrigar a veleidade de querer equiparar-se a este último. ${ }^{26}$

O artigo 134 do Código de Processo Civil dispóe que "é defeso ao juiz exercer as suas funçóes no processo contencioso ou voluntário: III - que conheceu em primeiro grau de jurisdição, tendo-lhe proferido sentença ou decisão". Assim, o correto seria o ministro do TSE que participou do julgamento naquela Corte Eleitoral dar-se por impedido no STF, em razão do disposto no artigo 134, III, do CPC.

Além do mais, a repetição de ministros do STF na composição da Corte do TSE fere o princípio do duplo grau de jurisdição. É imprescindível para que exista duplo grau de jurisdição, conforme Neves, ${ }^{27}$ a distinção entre os órgãos jurisdicionais (julgadores) que, respectivamente, proferem a primeira decisão e que a reexaminam.

Assim, tais decisóes, tomadas verticalmente sem que haja consenso e nem diálogo, são injustas e arbitrárias e somente tendem a enfraquecer a democracia.

Se o Brasil quis entrar na modernidade, com a utilização da tecnologia, deve estar disposto também a democratizar o conhecimento. Como se vê, o conhecimento técnico das urnas eletrônicas fica restrito aos técnicos do Tribunal Superior Eleitoral

${ }^{26}$ CRUZ. José Ribamar Ferreira da Silva. Prejudicialidade decorrente da presença de Ministros do Supremo Tribunal Federal na composição do Tribunal Superior Eleitoral: previsibilidade de votos. Disponível em: $<$ http://jus.uol.com.br/revista/texto/18638/prejudicialidade-decorrentedapresenca-deministros-dosupremo-tribunal-federal-na-composicao-do-tribunal-superior eleitoral-previsibilidade-de-votos $>$. Acesso em: 20 jan. 2014.

${ }^{27}$ NEVES, Daniel Amorim Assunção. Manual de direito processual civil. São Paulo: Método, 2010. p. 549. In: "Parece não existirem maiores discussôes a respeito do conceito de duplo grau de jurisdiçáo, entendido como a possibilidade de revisão da solução da causa, ou seja, a permissão de que a parte possa ter uma segunda opiniáo concernente à decisão da causa. Essa possibilidade de reexame da decisão da causa constitui o elemento básico do princípio ora analisado. A polêmica sobre o conceito do princípio do duplo grau de jurisdição se refere à espécie de revisão pela qual passará a decisão da causa; mais especificamente, se a revisão deverá ou não ser feita por órgáo jurisdicional hierarquicamente superior àquele que proferiu a decisão impugnada.” 
e a fabricação das urnas está restrita a uma empresa americana, Diebold. ${ }^{28}$ Como se vê, a tecnologia náo é genuinamente brasileira. Há, nesse ponto, um risco de que a Justiça Eleitoral náo esteja preparada para tanto, por ser um poder mais fechado. O risco, segundo Ulrich Beck, pode ser gerenciado, se apreendido e evitado, senáo pode se tornar uma catástrofe. No caso, a catástrofe seria o afastamento do cidadão das grandes decisóes e com isso a democracia sofreria um revés. Eis as ilaçóes de Ulrich Beck: ${ }^{29}$

As true as all such observations may be, they miss the most obvious point about risk: that is, the key distinction between risk and catastrophe. Risk does not mean catastrophe. Risk means the anticipation of catastrophe. Risks exist in a permanent state of virtuality, and only become "topical" to the extent that they are anticipated. Risks are not "real", they are becoming real (Joost van Loon). At the moment that risks become real (for example, in the form of a terrorist attack), they cease to be risks and become catastrophes. Risks have already moved elsewhere: to the anticipation of further attacks, inflation, new markets, wars or the reduction of civil liberties. Risks are always events that are threatening. Without techniques of visualization, without symbolic forms, without mass media, etc., risks are nothing at all. In other words, it is irrelevant whether we live in a world which is in fact or in some sense objectively safer than all other worlds; if destruction and disasters are anticipated, then this produces a compulsion to act.

This, in turn, conceals as irony, the irony of the promise of security made by scientists, companies and governments, which, in wondrous fashion, contributes to an increase in risks. Finding themselves accused in public of countenancing risk, ministers jump into rivers or get their children to eat hamburgers in order to

${ }^{28}$ REVISTA ELETRÔNICA VALOR ECONÔMICO. Disponível em: <http://www.valor.com.br/ arquivo/828171/diebold-e-alvo-de-acusacoes-de-fraude-contabil-nos-eua>. Acesso em: 23 dez. 2013. A companhia, que também venceu a maioria das licitaçôes do Tribunal Superior Eleitoral (TSE) nos últimos anos, deve entregar 165 mil urnas ao governo até agosto. O contrato, avaliado em R\$ 204 milhóes, prevê o fornecimento total de até 250 mil equipamentos. Em 2009, a subsidiária cresceu 15\% em faturamento, atingindo $\mathrm{R} \$ 1,15$ bilhão em vendas, sem incluir nessa conta as urnas eletrônicas. Mundialmente, a receita da Diebold foi de US\$ 2,7 bilhóes no ano passado. A companhia tem mais de 17 mil funcionários distribuídos por 90 países (Colaborou André Borges, de São Paulo).

${ }^{29}$ BECK, Ulrich. Vivir en la sociedad del riesgo mundial. Living in the world risk society. Documentos Cidob. Serie: Dinámicas interculturales. Número 8. Depósito legal: B-35.860-2004. ISSN: 16982568. Distribuye: Edicions Bellaterra, S. L. Navas de Tolosa, 289, bis, 08026. Barcelona, jul. 2007. p. 37-38. 
prove that everything is absolutely safe and under control, from which follows, as sure as night follows day, that every doubt cast, every accident, violates the basis of the unshakeable right to security, which appears to be promised (grifamos).

Ulrich Beck propóe uma democratização da ciência tecnológica; uma participação da sociedade nas tomadas de decisão a respeito dos riscos que ela quer correr e a "desmonopolização" da ciência. Afirma o autor: ${ }^{30}$

Nesse modelo de desenvolvimento, invoca-se a tradição da modernidade, voltada à ampliação da autoderminação. $\mathrm{O}$ ponto de partida é a avaliação de que, no processo de renovaçáo da sociedade industrial, as possibilidades de autodeterminação democrática são reduzidas institucionalmente. Inovaçóes técnico-econômicas, enquanto motores da constante transformação social, são de saída excluídas das possibilidades democráticas de participação, controle e resistência. Estão, portanto, contidas no modelo diversas das contradições que irrompem atualmente. [...]. Visto que a ciência, que contribuiu decisivamente para colocar tudo isto em funcionamento, se desonera dos resultados e abriga-se ela própria em escolhas nas quais tudo acaba sendo de um jeito ou de outro transformado pela modernidade, trata-se então - esta é a conclusão a que chegamos - de tornar publicamente acessível essa base decisória, seguindo de fato as regras previstas no livro de receitas da modernidade: democratização. $\mathrm{O}$ calejado instrumental do sistema político deve ser ampliado de modo a abarcar condições exteriores a ele. Para tanto, muitas são as variantes concebíveis e já em discussão. $\mathrm{O}$ espectro de propostas abarca desde controles parlamentares sobre os avanços tecnológicos das empresas, passando por "parlamentos da modernização", nos quais planos sejam abordados, avaliados e oferecidos por bancadas interdisciplinares de especialistas, até a integração de grupos de cidadãos no planejamento tecnológico e nos processos decisórios da política de pesquisa.

${ }^{30}$ BECK, Ulrich. Sociedade de risco: rumo a uma outra modernidade. Tradução Sebastião Nascimento. São Paulo: Editora 34, 2010. p. 332-333. 
Não se assustem se se chegar à conclusão de que para promover esse diálogo a realização das eleiçóes não pode e nem deve estar a cargo do poder Judiciário, ${ }^{31}$ uma vez que esse poder tem por essência decidir "dentro dos gabinetes", sem que haja discussôes mais aprofundadas sobre a questão. O Executivo e o Legislativo, portanto, teriam o papel principal nesse palco. Ao Judiciário seria deixado o papel de agir somente após a ocorrência de fraude ou ilícitos administrativos, civis ou penais, pois essa é sua competência originária e precípua. Nesse passo, não seria demais asseverar que uma "Agência Nacional Eleitoral, autarquia especial", pertencente ao Executivo federal, faria melhor o papel de realizar eleiçóes que o Judiciário, uma vez que estaria mais apta a democratizar as decisóes e, inclusive, com o controle desse último.

${ }^{31}$ GRINOVER, Ada Pellegrini; CINTRA, Antônio Carlos de Araújo; DINAMARCO, Cândido Rangel. Teoria geral do processo. 19. ed. São Paulo: Malheiros Editores, 2003. p. 157-158, 160. "O exercício do poder do Estado, quando dividido e distribuído por vários órgãos segundo critérios funcionais, estabelece um sistema de freios e contrapesos, sob o qual difícil se torna o arbítrio e mais facilmente pode prosperar a liberdade individual. É a célere separação de "Poderes", ainda hoje a base da organização do governo nas democracias ocidentais e postulado fundamental do Estado de Direito. [...]. Terceiro dos poderes do Estado na lição clássica de Montesquieu, o Judiciário não tem a importância política dos outros poderes, mas ocupa um lugar de destaque entre os demais, quando encarado pelo ângulo das liberdades e dos direitos individuais e sociais, de que constitui a principal garantia. A Constituição brasileira dedica-lhe o Cap. III do Tit. IV (art. 92, ss) e inscreve, entre os direitos e garantias individuais, o princípio da inafastabilidade da apreciação judiciária, segundo a qual "a lei não excluirá da apreciação do poder Judiciário lesão ou ameaça a direito" (artigo $5^{\circ}$, inc. XXXV). Principalmente em países que adotam o sistema da chamada jurisdição una (em que, contrariamente ao que ocorre onde há o contencioso administrativo, toda a funçáo jurisdicional é exercida pelo poder Judiciário, salvo raras exceçôes - v. n. seg.), avulta a importância do "terceiro poder", a quem é confiada a tutela dos direitos subjetivos até mesmo contra o poder público, e que tem a função de efetivar os direitos e garantias individuais, abstratamente inscritos na Constituição. Os direitos fundamentais, formulados pela Constituição por meio de normas necessariamente vagas e genéricas, quando violados ou postos em dúvida só podem ser afirmados, positivados e efetivados pelos tribunais. E a regulamentação das relaçôes jurídicas para a solução dos conflitos de interesses. É perante o poder Judiciário, portanto, que se pode efetivar a correçâo da imperfeita realização automática do direito: vãs seriam as liberdades do indivíduo se não pudessem ser reivindicadas e defendidas em juízo."[...]. Funçôes administrativas o Judiciário as exerce em variadas atividades inerentes ao autogoverno da Magistratura (Const., art. 96). Diante disso, podemos dizer que tudo quanto é atribuído ao poder Judiciário tem caráter genérico de atividade judiciária; esta compreende não só a funçáo jurisdicional (precípua do Judiciário, mas também atribuída a outros poderes), como ainda, em casos excepcionais e restritos, a administrativa e a legislativa." 
Assim, podemos partir de duas premissas básicas: o Judiciário não tem legitimidade para realizar eleiçóes em uma democracia e a tecnologia pode suplantar direitos fundamentais. Em ambas as hipóteses o princípio da precaução pode ser aplicado, secundo Jean Pierre Dupuy, que afirma: ${ }^{32}$

Quando um ator da "precaução" declara que, "em situação de riscos, uma hipótese não infirmada deveria ser tida provisoriamente como válida mesmo que ela não tenha sido formalmente demonstrada", a sua formulação vem arrastando toneladas de pressupostos filosóficos que se gostaria de ver explicitados.

Prosseguindo, as duas hipóteses são umbilicalmente ligadas, pois a ausência de legitimidade do Judiciário para conduzir eleiçôes no Estado Democrático de Direito, por não ter condiçóes de manter um diálogo com a sociedade, e o fato de que a tecnologia, conduzida por esse Judiciário, não preparado, pode suplantar direitos fundamentais, são moedas de um mesmo reverso. O dano que o Judiciário, com o manuseio errôneo da tecnologia, pode infligir à sociedade é muito grande. Assim sendo, deve-se reverter o processo no sentido de dar uma chance à democracia. Desse modo, não cabe ao cidadão provar que o sistema é frágil, mas ao Judiciário provar que não é, inclusive desapegando-se dele, deixando para outro poder geri-lo.

Sobre a questão, Jean Pierre Dupuy acentua que: ${ }^{33}$

Da mesma forma, o que há de mais conforme ao bom senso, no caso de danos potencialmente graves ou irreversíveis, considerar que mais vale errar para o lado da imputação de nocividade do que no sentido oposto? Cabe, pois, ao inovador, provar que o seu produto não é nocivo, a ausência de provas de que ele não seja é o bastante em absoluto para estabelecê-lo como nocivo. Um estudo inglês centrado em artigos científicos sobre engenharia genética mostra, entretanto, que eles cometem sistematicamente o sofisma da moeda registrado antes, muito embora aleguem estar aplicando o princípio de precaução. Essa inversão do ônus da prova seria exorbitante? Não, pois ela náo implica de maneira alguma que

${ }^{32}$ DUPUY, Jean-Pierre. O tempo das catástrofes: quando o impossível é uma certeza. São Paulo: É Realizaçóes Editora, 2011. p. 108-109.

${ }^{33}$ DUPUY, Jean-Pierre. O tempo das catástrofes: quando o impossível é uma certeza. São Paulo: É Realizaçóes Editora, 2011. p. 112-113. 
fique estabelecida a inocuidade perfeita. Ir "além da dúvida razoável”, isto é, levar a menos de $5 \%$ a probabilidade a priori de que os resultados de experiências que parecem confirmar a hipótese de inocuidade se devam ao acaso, supondo que a hipótese contrária ficasse comprovada, é uma tarefa cuja necessidade deveria ser reconhecida por todo indivíduo com mentalidade responsável. Cumpre provê-la de meios de pesquisa e de investigação suficientes. Todo mundo deveria concordar com isso sem dificuldade. O tipo de "catastrofismo" implicado na reversão do ônus da prova não extrapola assim em nada o perfeitamente razoável.

Deve-se, levando-se em contas essas premissas, a exemplo de Dupuy, idealizar o pior cenário. Nesse caso, seria a extinçáo parcial da democracia, pelo menos no que tange aos direitos políticos e a hegemonia do Judiciário sob o Executivo e Legislativo com o controle das "máquinas" que "fabricam" candidatos. A sociedade deveria confiar nesse poder na condução da tecnologia ainda não conhecida por completo?

Nesse ponto expressa Dupuy ${ }^{34}$ ao comentar os argumentos de Catherine Larrère:

Heurística do medo: vejam só que programa mais detestável, replica a crítica. Como é que se poderia deliberar, ou ao menos pensar, sob o domínio da angústia, tomado de pânico? Assim reage Catherine Larrère: “(...) a 'profecia da infelicidade' (...) exclui toda possibilidade de escolha. (...) A escolha do pior cenário proíbe todo debate democrático: sob a ameaça da catástrofe iminente, não se conseguiria deliberar." Creio ter detectado aqui um completo contrassenso. O ponto de partida de Jonas é, de forma totalmente oposta, o mesmo que o meu, a saber que a perspectiva da catástrofe não nos transtorna - não, não é nada disso! - ela nos deixa totalmente indiferentes. Como Bergson até a véspera da declaração de guerra, a catástrofe nos parece impossível. É justamente para arrombar esse trinco, que pertence à metafísica, muito mais do que à psicologia, que Jonas apregoa o que é antes de tudo um método. A heurística do medo não é deixar-se levar por uma correnteza de sentimentos, abdicando da razão; é fazer de um medo simulado, imaginado, o revelador do que tem para nós um valor incomparável.

${ }^{34}$ DUPUY, Jean-Pierre. O tempo das catástrofes: quando o impossível é uma certeza. São Paulo: É Realizaçóes Editora, 2011. p. 115-116. 
Assim, a sociedade deve ter medo do retrocesso, de um golpe à democracia, do "fechamento do sistema", da falta de diálogo do Judiciário, a ponto de incumbir a outro poder, que não o Judiciário, a realização das eleiçóes, exatamente porque a tecnologia e a técnica ${ }^{35}$ podem ser mais bem manipuladas pelo Executivo e Legislativo, talvez não controladas. E essa falta de diálogo já foi constatada pelo presidente Lula, em 2003, quando disse que o Judiciário era uma "caixa-preta, ${ }^{36 "}$ referindo-se à falta de transparência do Judiciário. E mereceu da ministra Eliana Calmon, então corregedora do Conselho Nacional de Justiça - CNJ, em 2012, referindo-se à “caixa-preta” do Judiciário, os seguintes comentários sobre um poder até então intocável: ${ }^{37}$

${ }^{35}$ CUNHA, Ricarlos Almagro Vitoriano. Segurança jurídica e crise no Direito. Belo Horizonte: Arraes Editores, 2011. p. 38-39. (Coleçâo professor Álvaro Ricardo de Souza Cruz). "Que dizer da técnica moderna? É ela também uma forma de desencobrimento, contudo, já não se dá em estreita conexão com essa relação originária que marca a produção como modo de deixar viger, e, sim, como uma exploração que desafia a natureza a fornecer recursos em uma séria dispositiva. Assim, o rio já não aparece em sua beleza contemplativa, ele já não é mais ouvido em seu correr sinuoso entre as rochas, ele já foi esquecido enquanto espaço do lazer infantil; o rio agora é apenas algo que se presta a movimentar as turbinas, as quais, por sua vez, dispōem-se a produzir energia, que será transmitida e armazenada, tornando-se disponível para a indústria, e assim sucessivamente seguimos em uma séria quase infinita em que o próprio homem se torna um instrumento, um dispositivo para a técnica. O grande risco dessa série é que o homem, pensando ser o produto de tudo isso que é disposto, imagina-se senhor do mundo, mas em verdade ele aí não se encontra, já não se acha em nenhum desses aparatos técnicos; ao contrário, perde-se em meio a eles, também disponível (vejamos o exemplo do homem como consumidor, disponível para a indústria do consumo). Portanto, a técnica não é simplesmente o operar da ciência na construção de aparatos; muito mais do que isso, a técnica é esse desalojar do sentido, é esse encobrimento do mundo da vida, do espaço da existência em que a liberdade transparece como marca do humano. Não estamos aqui nos referindo à ideia de liberdade em seu sentido usual, mas de liberdade como deixar viger o mundo. E é exatamente aí que a técnica nos estrangula, inviabilizando qualquer projeto existencial, pois todo sentido já se vê obstruído originariamente no âmbito da técnica, como modo de produção voltado para a disponibilidade. Todo e qualquer projeto instituído pelo homem já vem fundado e nivelado naquela cadeia de remissóes dispositivas que suprimem a sua liberdade e obscurecem os possíveis sentidos de tudo aquilo que poderia aparecer. [...]"

${ }^{36}$ BRASIL. Folha de São Paulo. Sombra do poder. Presidente endossa frase de Lampiâo contra distorçôes da Justiça. Lula critica "caixa-preta” do Judiciário e defende controle. Disponível em: <http://www1. folha.uol.com.br/fsp/brasil/fc2304200302.htm>. Acesso em: 4 jan. $2014 \mathrm{a}$.

${ }^{37}$ BRASIL. Jornal do Brasil. Calmon deixa Corregedoria, e diz que "caixa preta" do Judiciário está aberta. Disponível em: <http://www.jb.com.br/pais/noticias/2012/08/30/calmon-deixa-corregedoria-e-dizque-caixa-preta-do-judiciario-esta-aberta/>. Acesso em: 4 jan. $2014 \mathrm{~b}$. 
Encontramos em alguns tribunais desordem, corrupção, descaso, ou seja, encontramos de tudo no setor de precatórios. Ao deixar a Corregedoria, posso dizer que, pelo menos, despertei a atenção dos presidentes dos tribunais para a realidade. Hoje, eles sabem que são responsáveis diretos pelo setor, podendo até responder por crime de responsabilidade. Este alerta que foi dado aos tribunais foi o primeiro passo para começarmos a nos programar,

Resta saber se realmente a "caixa-preta" foi aberta e se a corrupção foi estancada por completo. Acredita-se que as açóes da ex-corregedora do CNJ foram apenas um alerta para o poder incontrolável que o Judiciário tem à sua disposição. Muito ainda deve ser feito para que esse poder seja realmente transparente.

Isso posto, tenha medo da tecnologia em mãos erradas, tenha medo de um poder que náo dialoga. Esse medo pode ser utilizado como termômetro para melhorar o futuro. Ele (medo) não o deixa atônito a ponto de não saber pensar, pois é apenas reverberação do medo real, conforme Hans Jonas afirma. ${ }^{38}$ Seria por esse motivo que se deve retirar do poder Judiciário as atribuiçóes de realizar eleiçóes,

38 JONAS, Hans. Princípio da responsabilidade: ensaio de uma ética para civilizaçāo tecnológica. Rio de Janeiro: Editora PUC Rio, 2006. p. 70-71. In.: "Esse elo intermediário de união e a concretizaçâo, que descreve as situaçôes futuras, não está separado da parte que se refere aos princípios fundamentais; ao contrário, ele está presente nesses próprios princípios, de modo heurístico. Assim como não saberíamos sobre a sacralidade da vida caso não houvesse assassinatos e o mandamento "não matarás" não revelasse essa sacralidade, e não saberíamos o valor da verdade se não houvesse a mentira, nem o da liberdade sem a sua ausência, e assim por diante - assim também, em nosso caso, na busca da ética da responsabilidade a longo prazo, cuja presença ainda não se detecta no plano real, nos auxilia antes de tudo a previsão de uma deformação do homem, que nos revela aquilo que queremos preservar no conceito de homem. Precisamos da ameaça à imagem humana - e de tipos de ameaça bem determinados - para, com o pavor gerado, afirmarmos uma imagem humana autêntica. Enquanto o perigo for desconhecido não se saberá o que há para se proteger e por que devemos fazê-lo; por isso, contrariando toda lógica e método, o saber se origina daquilo contra o que devemos nos proteger. Este aparece primeiro e, por meio da sublevação dos sentimentos, que se antecipa ao conhecimento, nos ensina a enxergar o valor cujo contrário nos afeta tanto. Só sabemos o que está em jogo quando sabemos que isto ou aquilo está em jogo. Pois assim se dáo as coisas conosco: o reconhecimento do malum é infinitamente mais fácil do que o do bonum; é mais imediato, mais urgente, bem menos exposto a diferenças de opinião; acima de tudo, ele não é procurado: o mal nos impóe a sua simples presença, enquanto o bem pode ficar discretamente ali e continuar desconhecido, destituído de reflexão (esta pode exigir uma razão especial). Não duvidamos do mal quando com ele nos deparamos; mas só temos certeza do bem, no mais das vezes, quando dele nos desviamos. É de se duvidar que alguém, alguma vez, tenha feito o elogio da saúde sem pelo menos ter visto o espetáculo da doença, o elogio da decência sem ter eoncontrado a patifaria, e o da paz sem conhecer a miséria da guerra. O que nós não queremos, sabemos muito antes do que aquilo que queremos. Por isso, para investigar o que realmente valorizamos, a filosofia da moral tem de consultar 
partindo da premissa de que não entendem e não podem controlar a tecnologia/ técnica? Deve-se olhar o presente entrelaçado ao futuro, para se tentar antecipar o pior cenário. Dupuy assim se expressa: ${ }^{39}$

Nem consequencialismo, nem deontologia. O que nos resta exatamente? Talvez fosse recomendável levar a sério a heurística do medo que nos propõe Jonas, bem como a ética do porvir, ou do futuro (Zukunft), que a acompanha.

A ética de Jonas não é consequencialista. Nós o compreenderemos melhor pelo que virá na sequência. Nesta altura, digamos que a razáo profunda pela qual ela não é tem a ver com a direção do tempo. $\mathrm{O}$ consequencialismo procede do presente rumo ao futuro, como a etimologia de "consequiência" demonstra claramente: o que acompanha vindo depois. A ética do futuro não é a que prevalecerá, ou deveria prevalecer no porvir. É a ética que constrói quando se olha o presente, o nosso presente, do ponto de vista do futuro. Essa inversão é que faz, no plano metafísico, a perfeita especificidade, a originalidade de profunda e a beleza da ética proposta por Jonas. [....]

Por sua vez, Hans Jonas explica o que se deve entender por heurística do medo: ${ }^{40}$

É nesse vácuo, que simultaneamente também é o vácuo do relativismo de valores atual, que a presente pesquisa assume posição. O que pode servir como bússola? A previsão do perigo. Antes de tudo nos seus relâmpagos surdos e distantes, vindos do futuro, na manifestaçáo de sua abrangência planetária e na profundidade de seu comprometimento humano podem revelar-se os princípios éticos dos quais se permitem deduzir as novas obrigaçôes do novo poder. Eu denomino isso "heurística do medo": somente entẫo, com a antevisão da desfiguração do homem, chegamos ao conceito de homem a ser preservado. Só sabemos o que

o nosso medo antes do nosso desejo. E, embora aquilo que mais tememos não seja necessariamente o mais temível, e o seu contrário não seja, menos necessariamente ainda, o bem supremo (que pode ser inteiramente independente da oposição a um mal) - embora, portanto, a heurística do medo não seja a última palavra na procura do bem, ela é uma palavra muito útil. Sua potencialidade deveria ser plenamente utilizada, em uma área em que tão poucas palavras nos são dadas graciosamente."

${ }^{39}$ DUPUY, Jean-Pierre. O tempo das catástrofes: quando o impossível é uma certeza. São Paulo: É Realizaçóes Editora, 2011. p. 191.

40 JONAS, Hans. Princípio da responsabilidade: ensaio de uma ética para civilizaçáo tecnológica. Rio de Janeiro: Editora PUC Rio, 2006. p. 21. 
está em jogo quando sabemos que está em jogo. Como se trata não apenas do destino do homem, mas também da imagem do homem, não apenas de sobrevivência física, mas também da integridade de sua essência, a ética que deve preservar ambas, precisa ir além da sagacidade e tornar-se uma ética do respeito.

A dificuldade de diálogo entre instituiçôes e cidadãos (no caso, entre Judiciário na condução da melhor tecnologia para realização de eleições) já foi colocada em xeque por Lenio Luiz Streck, ${ }^{41}$ quando discorre sobre a teoria de Habermas.

${ }^{41}$ STRECK, Lenio Luiz. Verdade e consenso: constituição, hermenêutica e teorias discursivas. Rio de Janeiro: Lumen Juris Editora, 2006, p. 157-158. “Daí a indispensável indagação: como ter cidadãos plenamente autônomos, como Habermas propugna, se o problema da exclusão social não foi resolvido? Mais: como ter cidadãos plenamente autônomos se suas relações estão colonizadas pela tradição que lhes conforma o mundo da vida? Por tais razóes, Ackerman indaga: pode uma eleição ser livre e justa, se uma grande parte do eleitorado carece de instruçáo necessária para compreender as principais linhas do debate político? Ou se estão passando fome ou trabalhando em condiçôes opressivas durante a maior parte de seu tempo? "Minha resposta é não", vai dizer Ackerman: se você está de acordo, este primeiro fundamento lhe permite preparar um caminho conceitual para considerar até onde os juízes deveriam estar facultados constitucionalmente para intervir também nessas questóes. Por conseguinte, a concessão de uma faculdade semelhante pode ver-se limitada por toda a sorte de consideraçôes predicais. Porém, o que interessa aqui, acentua o professor norte-americano, são os princípios básicos: ao habilitar os juízes para insistir em um "piso democrático" na avaliaçáo de medida de bem-estar e educacionais propostas pelos governantes, não se está advogando a "morte do político", e, sim, a sua reorganizaçáo e extensão, que deve abarcar desde um interesse pelo centro de decisóes até a proteçáo da vida política que se experimenta na periferia. No fundo, quando Habermas apresenta sua tese do sujeito autônomo, coloca-se ao lado da realidade, pondo-a entre parênteses, embora, evidentemente, não a negue. A exemplo de Husserl, Habermas não visa à realidade como uma construção ontológica, mas como necessidade de ser recuperada pela descrição dos atos conscientes, da consciência transcendental. Nesse sentido, o lugar da autonomia exsurgiria de um como (wie) dos fenômenos sociais. Esse como (wie) assume uma característica epistemológica, em que o procedimento é o meio para alcançar essa autonomia do sujeito. Essa minha crítica é contestada, entre outros, por Gesta Leal, ao dizer que "a possibilidade de emancipaçâo humana dos grilhôes conjunturais que aprisionam o sujeito histórico habermasiano se viabiliza pela (hipótese-argumentativa) capacidade racional de interlocuçáo caracterizadora do homem moderno, operada a partir de procedimentos e instâncias democrático-igualitárias compromissadas com o entendimento persuasivo dos melhores argumentos. De minha parte, continuo a indagar: como se constroem esses procedimentos e instâncias democrático-igualitárias, por exemplo, na África, no Brasil ou na Bolívia? Essa pergunta parece de difícil resposta. Aliás, não há registros de que já tenha sido proposto um discurso de fundamentaçáo (prévio) acerca de como devem ser esses procedimentos e de que modo se forma a condição ideal de fala, como função contrafática. Por isso, a minha insistência no sentido de que a teoria habermasiana náo se destina a países como o Brasil, em que as condiçóes para a formulação dos requisitos que levaráo à emancipação dos sujeitos sociais são absolutamente precárias. Aliás, repita-se - e se faça justiça a Habermas: sua preocupação não é com o Brasil, conforme ele mesmo deixou claro em conferência no Rio de Janeiro há alguns anos. E não consta que tenha corrigido a assertiva de lá para cá.” 
Diferentemente de Lenio Streck, entende-se que não há obstáculo para esse diálogo no plano da administração, da gestáo da coisa pública, da gestão da tecnologia. A questão não é fácil, todavia deve-se ater a seguinte premissa: a liberdade somente é conhecida se vivenciada, portanto a democracia igualitária deve ser instituída para que o cidadáo a vivencie, de modo a senti-la e fazer parte dela, realizando-a cotidianamente. Ora, “a vitória do cristianismo sobre a filosofia grega ${ }^{42}$ ” se deu com premissa de que os homens são iguais em dignidade, ${ }^{43}$ contrariando o que a Filosofia grega pregava à época, ou seja, a existência de uma hierarquia entre os homens, o que, inclusive, legitimava a escravidão. E, porventura, essa premissa fundida há milênios ainda não vigora até nossos tempos? Naturalmente, que sim, mas em menor ou maior grau, dependendo da sociedade.

Mesmo nos países desenvolvidos, o cidadão dito esclarecido não vivencia uma democracia igualitária, pois a tomada de poder passa por grandes organizaçóes, tais como partidárias, religiosas, sindicais. Aí, não há a desculpa que o cidadão não tem condiçôes culturais, educacionais. A questão, portanto, não passa pelas condições precárias, tais como pobreza, falta de instrução do cidadão, mas sim de colocar à disposição do povo o que lhe é direito. Seu entendimento acerca do funcionamento da política, da economia, da sociedade como um todo ocorrerá paulatinamente, na medida em que se aprofunda no emaranhado da (re)construção diária do homem político. ${ }^{44}$

${ }^{42}$ FERRY, Luc. Aprender a viver: filosofia para os novos tempos. Tradução Vera Lucia dos Reis. Rio de Janeiro: Objetiva, 2010. p. 78-96.

${ }^{43}$ FERRY, Luc. Aprender a viver: filosofia para os novos tempos. Tradução Vera Lucia dos Reis. Rio de Janeiro: Objetiva, 2010. p. 96. "O cristianismo vai trazer até ela a noção de que a humanidade é fundamentalmente uma e que os homens são iguais em dignidade - ideia incrível na época, e da qual nosso universo democrático será em parte herdeiro. [...]”

${ }^{44}$ BECK, Ulrich. Sociedade de risco: rumo a uma outra modernidade. Tradução Sebastiāo Nascimento. São Paulo: Editora 34, 2010. p. 337-338. "Por trás da mudança histórica, ocultam-se também pontos de partida para uma democratizaçáo estrutural consideravelmente mais manejável. Esta teve seu início com o princípio da divisão dos poderes (e, nessa medida, já está contida no modelo da sociedade industrial), tendo sido ampliada, entre outras razóes, por conta da liberdade de imprensa. 
Nesse processo os adversários são os próprios poderes constituídos, e se não se repensar as funçôes da Justiça Eleitoral no Brasil poderá haver um grande retrocesso na consecução de alguns direitos fundamentais do cidadão, tais como democracia, publicidade, participação efetiva na política. Desse modo, são bem lançadas as palavras de Dupuy acerca dessa luta do homem contra o homem: ${ }^{45}$

\begin{abstract}
A humanidade não está envolvida em um jogo MAD com adversários cujo nome seria a Natureza, a Técnica ou o tempo. Se, como Édipo, a humanidade partisse em busca do culpado, é ela própria que encontraria no fim do caminho. É só com ela mesma que ela tem de haver-se por trás das mediaçōes naturais e artificiais que evitam que os homens caiam uns sobre os outros se matando em uma confusão geral. Nessa história toda só há um protagonista, mesmo que o mal que o espreita tome a forma do destino. Esse destino não é um sujeito e ele
\end{abstract}

O fato de que o sistema econômico seja um campo no qual não só avanços são gerados sob a forma de imprevistos efeitos colaterais do interesse próprio e de necessidades técnicas, mas também a sólida (sub) política é praticada no sentido de uma transformação política igualmente possível por outros meios, é algo que se acaba por se desvelar, no mais tardar hoje, a partir do momento em que a "necessidade técnico-econômica" da emissão de poluentes subitamente se reduz, sob pressão pública, a uma de várias outras possibilidades decisórias. O fato de que a situação por trás das paredes da esfera privada nem sempre teve de seguir os padróes do casamento e da família, dos papéis masculino e feminino, é algo de que qualquer um historicamente ilustrado já havia suspeitado, mas que somente por meio das destradicionalizaçóes pôde ser integrado à esfera do conhecimento e, mais ainda: das decisóes. Ao legislador não se concede nem o direito e nem a possibilidade de intervir neste aspecto. $\mathrm{O}$ "governo paralelo da privacidade" pode modificar aqui e agora as relaçôes de convivência sem ter de recorrer a projetos de lei ou a fórmulas decisórias, e efetivamente o faz, como demonstram as expansivas, oblíquas e cambiantes condiçóes de vida. A visão sobre esse processo é obstruída cada vez mais pela intactamente preservada fachada de realidade da sociedade industrial. A avaliação defendida aqui é a seguinte: atualmente, escancaram-se os monopólios que surgiram com a sociedade industrial, estando incrustados em suas instituiçóes, escancaram-se monopólios, mas nenhum mundo desmorona: o monopólio de racionalidade da ciência, o monopólio profissional dos homens, o monopólio sexual do casamento, o monopólio político da política. Tudo isto fragiliza-se pelas mais diversas razóes, produzindo efeitos bastante variados, imprevistos, ambivalentes. Mas cada um desses monopólios também contradiz os princípios que foram implementados com a modernidade. O monopólio de racionalidade da ciência excluiu o autoceticismo. $\mathrm{O}$ monopólio profissional dos homens opóe-se às demandas universalistas por igualdade, sob cujo manto a modernidade teve início, e por aí adiante. Isto também significa: muitos riscos e questôes emergem na continuidade da modernidade, sendo validados contra a contração de seus princípios no projeto da sociedade industrial. O outro lado da incerteza que a sociedade de risco lança sobre a atormentada humanidade é a chance de que mais da igualdade, da liberdade e da autodeterminação que a modernidade promete seja obtido e ativado contra as limitaçóes, os imperativos funcionais e o fatalismo do progresso da sociedade industrial. [...]."

${ }^{45}$ DUPUY, Jean-Pierre. O tempo das catástrofes: quando o impossível é uma certeza. São Paulo: É Realizaçōes Editora, 2011. p. 255-256. 
não tem intenções. Porém a situação de "destruição mútua garantida” terá tido a mesmíssima estrutura. Sob a aparência de dois gêmeos inextricavelmente ligados pela sua rivalidade mimética, encontra-se um só ator, a humanidade uma vez mais, às voltas com a sua própria violência, que toma a forma de um destino apocalíptico. Nos dois casos, o mal não é nem assinado nem reivindicado. Ele é sem intenção. A astúcia consiste não em revelar que ele não existe, mas em agir como se fôssemos as suas vítimas, conservando a consciência clara de que somos a causa única do que acontece conosco. Esse jogo duplo, esse estratagema, é talvez a condição necessária da nossa salvação.

Norberto Bobbio acertadamente aponta pelos menos três razóes para a crise da democracia: ${ }^{46}$

Quando comparada à democracia de inspiração rousseauística, com efeito, a participação popular nos Estados democráticos reais está em crise por pelo menos três razóes: a) a participação culmina, na melhor das hipóteses, na formação da vontade da maioria parlamentar; mas o parlamento, na sociedade industrial avançada, não é mais o centro do poder real, mas apenas, frequentemente, uma câmara de ressonância de decisóes tomadas em outro lugar; b) mesmo que o parlamento ainda fosse o órgão do poder real, a participação popular limita-se a legitimar, a intervalos mais ou menos longos, uma classe política restrita que tende à própria autoconservação, e que é cada vez menos representativa; c) também no restrito âmbito de uma eleição una tantum sem responsabilidades políticas diretas, a participação é distorcida, ou manipulada, pela propaganda das poderosas organizaçóes religiosas, partidárias, sindicais, etc., A participação democrática deveria ser eficiente, direta e livre: a participação popular, mesmo nas democracias mais evoluídas, não é nem eficiente, nem direta, nem livre. Da soma desses três déficits de participação popular nasce a razão mais grave de crise, ou seja, a apatia política, o fenômeno, tantas vezes observado e lamentado, da despolitização das massas nos Estados dominados pelos grandes aparelhos partidários. A democracia rousseauísta ou é participativa ou não é nada.

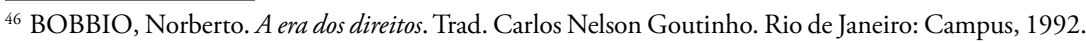
p. 151. 
Por isso, afirma-se que o problema da não participação do cidadão na tomada de decisão da gestão administrativa ou mesmo no processo jurisdicional não passa pelas condiçóes de país de terceiro mundo, mas sim pelo afastamento do sujeito da administração pública pelas organizaçóes que realmente detêm o poder, aí se incluem partidos, sindicatos, os poderes constituídos, Judiciário, Legislativo, Executivo, etc. O cidadáo é alijado de seus direitos por aqueles que dizem que eles não conseguem entender a República como um todo. Assim, necessitam de interlocutores tais como partidos, Organizaçóes Não Governamentais, Ministério Público, etc. Vale lembrar o alerta de Maciel Júnior, citado por Roberta Maia Gresta et al., que "coloca nas mãos de interlocutores autorizados a prerrogativa de, a partir de sua própria percepção, definir o sentido do que seja o interesse de toda a coletividade." ${ }^{47}$

\section{CONSIDERAÇÕES FINAIS}

A Justiça Eleitoral como integrante do poder Judiciário não está preparada para a condução da utilização da tecnologia de forma democrática, como é necessário num país em que a democracia tem caráter fundante. ${ }^{48}$ Para a condução desse processo necessário se faz o diálogo com toda a sociedade civil, papel historicamente reservado ao Executivo e Legislativo. Ao Judiciário é destinado papel importante também, que é dirimir os conflitos existentes entre as várias pessoas componente do Estado, sendo certo que ao STF, como Tribunal Constitucional, incumbe a salvaguarda da Constituição Federal.

Assim, o processo eletrônico de votação iniciado com a Justiça Eleitoral não deve continuar sob a sua tutela, sob pena de subtrair dos cidadãos direitos fundamentais previstos na Constituição Federal, tais como o direito à democracia e à publicidade.

${ }^{47}$ GRESTA, Roberta Maia; FERREIRA, Lara Marina; BRACARENSE, Mariana Sousa. Coletânea de artigos jurídicos NAP 2011. Igor Alves Noberto Soares et al. (Org.). Parâmetros de legitimidade da atuação dos partidos políticos no processo jurisdicional eleitoral. 1. ed. Curitiba, PR: CRV, 2012. p. 235.

${ }^{48}$ LORENZETTI. Ricardo Luis. Teoria da decisão judicial. Fundamentos de Direito. Tradução Bruno Miragem. Notas e revisão da tradução Cláudia Lima Marques. 1. ed. São Paulo: Ed. Revista dos Tribunais, 2009. p. 102. 
A tecnologia/técnica deve ser levada ao conhecimento do cidadão para que ele possa opinar sobre o melhor modelo para o país. Esse amplo diálogo passa pelos verdadeiros interlocutores, os cidadãos.

\section{REFERÊNCIAS}

AMARAL, Roberto; CUNHA, Sérgio Sérvulo da. Manual das eleiçôes. São Paulo: Saraiva, 2006.

BANDEIRA, André. Os limites da democracia - a influência do Direito Democrático europeu e uma nova guerra. Revista do Instituto dos Advogados de Minas Gerais, Belo Horizonte: IAMG, n. 1, 1995.

BARROSO, Lucas Abreu. A obrigação de indenizar e a determinação da responsabilidade civil por dano ambiental. Rio de Janeiro: Forense, 2006.

BECK, Ulrich. Sociedade de risco: rumo a uma outra modernidade. Tradução Sebastião Nascimento. São Paulo: Editora 34, 2010.

- Vivir en la sociedade del riesgo mundial. Living in the world risk society. Documentos Cidob. Serie: Dinámicas interculturales. Número 8. Depósito legal: B-35.860-2004. ISSN: 1698-2568. Distribuye: Edicions Bellaterra, S. L. Navas de Tolosa, 289, bis, 08026. Barcelona, jul. 2007.

BOBBIO, Norberto. A era dos direitos. Trad. Carlos Nelson Goutinho. Rio de Janeiro: Campus, 1992.

BRASIL. Folha de São Paulo. Sombra do poder. Presidente endossa frase de Lampião contra distorçóes da Justiça. Lula critica "caixa-preta” do Judiciário e defende controle. Disponível em: <http://www1.folha.uol.com.br/fsp/brasil/fc2304200302.htm>. Acesso em: 4 jan. $2014 a$.

. Informatização da JE. Histórico. Infraestrutura e logística. Avaliação do sistema. Disponível em: <http://www.tse.jus.br/eleicoes/biometria-e-urna-eletronica/eleicoes >. Acesso em: 20 dez. 2013.

- Jornal do Brasil. Calmon deixa Corregedoria, e diz que "caixa preta" do Judiciário está aberta. Disponível em: <http://www.jb.com.br/pais/noticias/2012/08/30/calmon-deixa-corregedoria-e-diz-que-caixa-preta-do-judiciario-esta-aberta/>. Acesso em: 4 jan. $2014 \mathrm{~b}$. 
CARVALHO, Kildare Gonçalves. Direito Constitucional. 10 ed., rev., atual. e ampl. Belo Horizonte: Del Rey, 2004.

COMITE MULTIDISCIPLINAR INDEPENDENTE. Relatório sobre o sistema brasileiro de votaçâo eletrônica. Disponível em: <http://www.brunazo.eng.br/voto-e/textos/RelatorioCMind.pdf>. Acesso em: $22 \mathrm{dez} .2013$.

COSTA, Tito. Recursos em matéria eleitoral. 4. ed., ampliada e atualizada de acordo com a Constituição de 1988. São Paulo: Editora Revista dos Tribunais, 1992.

CRUZ, José Ribamar Ferreira da Silva. Prejudicialidade decorrente da presença de Ministros do Supremo Tribunal Federal na composição do Tribunal Superior Eleitoral: previsibilidade de votos. Disponível em: <http://jus.uol.com.br/revista/texto/18638/prejudicialidade-decorrentedapresenca-deministros-do-supremo-tribunal-federal-na-composicao-do-tribunal-superior eleitoral-previsibilidade-de-votos>. Acesso em: 20 jan. 2014.

CUNHA, Ricarlos Almagro Vitoriano. Segurança jurídica e crise no Direito. Belo Horizonte: Arraes Editores, 2011. (Coleção professor Álvaro Ricardo de Souza Cruz).

DUPUY, Jean-Pierre. O tempo das catástrofes: quando o impossível é uma certeza. São Paulo: É Realizaçóes Editora, 2011.

FERRY, Luc. Aprender a viver: filosofia para os novos tempos. Tradução Vera Lucia dos Reis. Rio de Janeiro: Objetiva, 2010.

GOMES, José Jairo. Direito Eleitoral. 3. ed. Belo Horizonte: Del Rey, 2010.

GRESTA, Roberta Maia; FERREIRA, Lara Marina; BRACARENSE, Mariana Sousa. Coletânea de artigos jurídicos NAP 2011. Igor Alves Noberto Soares et al. (Org.). Parâmetros de legitimidade da atuação dos partidos politicos no processo jurisdicional eleitoral. 1. ed. Curitiba, PR: CRV, 2012.

GRINOVER, Ada Pellegrini; CINTRA, Antônio Carlos de Araújo; DINAMARCO, Cândido Rangel. Teoria geral do processo. 19. ed. São Paulo: Malheiros Editores, 2003.

JONAS, Hans. Princípio da responsabilidade: ensaio de uma ética para civilização tecnológica. Rio de Janeiro: Editora PUC Rio, 2006.

LOBO, Edilene. A inclusão do cidadão no processo eleitoral. Belo Horizonte: Del Rey, 2010.

LORENZETTI. Ricardo Luis. Teoria da decisão judicial. Fundamentos de Direito. Tradução Bruno Miragem. Notas e revisão da tradução Cláudia Lima Marques. 1. ed. São Paulo: Ed. Revista dos Tribunais, 2009. 
NEVES, Daniel Amorim Assunção. Manual de Direito Processual Civil. São Paulo: Método, 2010.

REVISTA ELETRÔNICA VALOR ECONÔMICO. Disponível em: <http://www.valor. com.br/arquivo/828171/diebold-e-alvo-de-acusacoes-de-fraude-contabil-nos-eua>. Acesso em: 23 dez. 2013.

STRECK, Lenio Luiz. Verdade e consenso: constituição, hermenêutica e teorias discursivas. Rio de Janeiro: Lumen Juris Editora, 2006.

TRIBUNAL SUPERIOR ELEITORAL. Urna eletrônica. Voto impresso. Disponível em: <http://www.tse.jus.br/eleicoes/biometria-e-urna-eletronica/urna-eletronica>. Acesso em: 20 dez. 2013. 